\title{
International competitiveness and potential for trade cooperation on clean energy between the USA and China
}

\author{
Yaowu Dong ${ }^{1}$, Xuesong $\mathrm{Li}^{2}$, Jie $\mathrm{Wu}^{3}$, and Yaoyao $\mathrm{Liu}^{4}$ \\ ${ }^{1}$ Guizhou University of Commerce,Guiyang,China 550014 \\ ${ }^{2}$ Taizhou University, Taizhou, China 225300 \\ ${ }^{3}$ Taizhou University, Taizhou, China 225300 \\ ${ }^{4}$ Guizhou University of Commerce, Guiyang,China 550014 \\ Corresponding address: 2247764011@qq.com
}

\begin{abstract}
As two super powers in energy consumption and carbon emission, the United States and China have been striving to develop clean energy in recent years. In this paper, we study the international competitiveness and potential for trade cooperation in clean energy between the two countries. This paper reveals that the United States has comparative advantages in terms of biomass energy and nuclear power, while China has comparative advantages in terms of solar energy and wind energy. The two countries have a strong complementarity in solar energy, biomass energy and nuclear energy with exporting from the United States and importing from China. In solar energy and wind energy a strong complementarity has been formed with exporting from China and importing into the United States. So the two countries have a strong potential for cooperation. Meanwhile, the potential trade cooperation is enhancing with the United States accelerating the development and exportation in natural gas. Therefore, the two countries have a strong trade complementarity on clear energy and a strong potential for cooperation in general. At the same time, the VCR model is built based on the clean energy Trade Complementary Index $\left(\mathrm{TCI}_{\mathrm{c}}\right.$ and $\left.\mathrm{TCI}_{\mathrm{u}}\right)$ between the United States and China. It can be found that the clean energy trade cooperation helps to curb $\mathrm{CO}_{2}$ emissions and promotes the GDP growth in the United States. However, China is in the early stage of clean energy development, the cooperation would cause a decline of GDP in China.
\end{abstract}

\section{Introduction}

With the improvement of people's living standards, various countries are paying more and more attention to environmental improvement. As two super powers in energy consumption and carbon emission, the United States and China are devoted themselves to the development and utilization of clean energy successively. In 2017, in the American energy consumption structures, the proportion of consumption in coal, oil and clean energy(natural gas, nuclear power, water power, terrestrial heat, solar energy, wind energy,biomass energy and so on)is respectively: $13.8 \%, 40 \%, 46.2 \%$; the corresponding proportion of consumption in China is respectively: $58.2 \%, 19.6 \%, 22.2 \%$. However, it's obvious that there is room for further optimization in the energy structure for both countries. Especially in China, the coal consumption is too high which makes energy saving and emission reduction under great pressure. In addition, if coal and other traditional energy account for a high proportion in the energy consumption structures, the efficiency of energy will decrease [1]. To maintain the sustainable development of economy, under the condition of limited energy resources, it is bound to improve energy consumption structures, improve the efficiency of energy, relieve the increase of energy consumption, it's also the effective measure to mitigate carbon emission [2].

The paper takes clean energy as the research object, analyze the international competitiveness, current situation and potential of trade cooperation from the view of trade between the United States and China. It also puts forward some relevant policy suggestions.

\section{Methods and Data}

\subsection{Methods}

Trade measures have always been central to measuring countries'comparative advantage, competitiveness, industries and product specializations [3]. The revealed comparative advantage (RCA) index is often used to measure the international competitiveness of certain industries [4-5]. The revealed comparative advantage (RCA) index was proposed by Balassa [6]. Balassa's RCA index is useful to evaluate whether a certain country has comparative advantages in the exports of a given commodity with regard to a certain group of countries [7]. Revealed Comparative Advantage reckons 
the magnitude of comparative advantage that a country enjoys in exports of various goods [8]. RCA is calculated as follows:

$$
\mathrm{RCA}_{\mathrm{ik}}=\left(\mathrm{X}_{\mathrm{ik}} / \mathrm{X}_{\mathrm{i}}\right) /\left(\mathrm{X}_{\mathrm{wk}} / \mathrm{X}_{\mathrm{w}}\right)
$$

Which $\mathrm{RAC}_{\mathrm{ik}}$ represents revealed comparative advantage index in $\mathrm{i}$ country $\mathrm{k}$ industry, $\mathrm{X}_{\mathrm{ik}}$ represents value of export in i country $\mathrm{k}$ industry, $\mathrm{X}_{\mathrm{wk}}$ represents value of export the whole word, $X_{i}$ represents total export in i country, $\mathrm{X}_{\mathrm{W}}$ represents total export the whole word. So, the RCA index of country $\mathrm{j}$ for commodity $\mathrm{k}$ is measured by the commodity k's share in the country's exports in relation to its share in world trade. While the Balassa index provides some insight into a country's international competitiveness, it is biased as it fails to capture the demand side by considering imports, especially when the country-size effect is significant [9].

To deal with problems existence in RAC, Vollrath [10] put forward the revealed competitiveness (RC) index to measure international competitiveness. The RC index does not rely only on exports but rather also incorporates imports. The RC is given by the formula:

$$
\mathrm{RC}_{\mathrm{ik}}=\ln \left[\left(\mathrm{X}_{\mathrm{ik}} / \mathrm{X}_{\mathrm{i}}\right) /\left(\mathrm{X}_{\mathrm{wk}} / \mathrm{X}_{\mathrm{w}}\right)\right]-\ln \left[\left(\mathrm{M}_{\mathrm{ik}} / \mathrm{M}_{\mathrm{i}}\right) /\left(\mathrm{M}_{\mathrm{wk}} / \mathrm{M}_{\mathrm{w}}\right)\right]
$$

The definition of $X_{i k}, X_{i}, X_{w k}, X_{w}$ is same to formula(1). $M_{i k}$ represents valume of imports in i country $\mathrm{k}$ industry, $\mathrm{M}_{\mathrm{i}}$ represents gross import value in i country, $\mathrm{M}_{\mathrm{wk}}$ represents valume of imports in $\mathrm{k}$ industry, $\mathrm{M}_{\mathrm{w}}$ represents gross import value the whole word. If $\mathrm{RC}>0$, relative competitive advantages is strong. Otherwise it is weak. Drysdale [11] put forward Trade Complementarity Index, it usually measures the corresponding relationship of product structure between import country and export country [12], it also reflects the potential development of the commodity trade between two countries (or regions) The specific formula is as follows:

$$
\mathrm{TCI}_{\mathrm{ij}}=\mathrm{RX}_{\mathrm{ik}} \times \mathrm{RM}_{\mathrm{ik}}
$$

where: $\mathrm{RX}_{\mathrm{ik}}$ is Balassa's revealed comparative advantage, $\mathrm{RX}_{\mathrm{ik}}=\left(\mathrm{X}_{\mathrm{ik}} / \mathrm{X}_{\mathrm{i}}\right) /\left(\mathrm{X}_{\mathrm{wk}} / \mathrm{X}_{\mathrm{w}}\right) ; \mathrm{RM}_{\mathrm{ik}}=\left(\mathrm{M}_{\mathrm{ik}} / \mathrm{M}_{\mathrm{i}}\right) /$.

$\left(\mathrm{M}_{\mathrm{wk}} / \mathrm{M}_{\mathrm{w}}\right)$, the definition of $\mathrm{X}_{\mathrm{ik}}, \mathrm{X}_{\mathrm{i}}, \mathrm{X}_{\mathrm{wk}}, \mathrm{X}_{\mathrm{w}}$ are same to the formula(1), the definition of $\mathrm{M}_{\mathrm{ik}}, \mathrm{M}_{\mathrm{i}}, \mathrm{M}_{\mathrm{wk}}, \mathrm{M}_{\mathrm{w}}$ are same to the formula(2); TCI depicts how specialization in the commodity composition of nation i's exports to the global market meshes with the specialization in the commodity composition of nation j's imports from the international market.Generally, if $\mathrm{TCI}>1$, the trade complementarity is strong, otherwise it is weak.

In order to have an in-depth study of the clean energy trade between the United States and China, considering the establishment of VAR model based on trade complementarity index (TCL). Vector autoregression (VAR) is a model used to reflect the linear inter-dependencies among multiple time series. For each endogenous variable, there exists a unique equation showing its evolution based on its own lags and the lags of other variables. Typically, VAR requires a list of variables that may affect each other intertemporally [13]. On the one hand, the clean energy trade cooperation will have an impact on economic growth, on the other hand, the increase of the proportion of clean energy consumption will help decrease the consumption of traditional energy like coal. Thus,it has a certain inhibition on $\mathrm{CO}_{2}$ emissions. In the establishment of VCR model, the endogenous variables are TCI $\left(\mathrm{TCI}_{\mathrm{u}}\right.$ and $\left.\mathrm{TCI}_{\mathrm{C}}\right), \mathrm{GDP}\left(\mathrm{GDP}_{\mathrm{c}}, \mathrm{GDP}_{\mathrm{u}}\right)$ and $\mathrm{CO}_{2}$, the exogenous variables is OPRICE. Since the use of clean energy is relatively small internationally, the price of crude oil has a direct impact on the price of clean energy, while the price of clean energy has a small impact on the price of crude oil. The specific form of VCR model is as follows:

$$
\mathrm{Y}_{\mathrm{t}}=\mathrm{C}+\mathrm{A}_{1} \mathrm{Y}_{\mathrm{t}-1}+\ldots+\mathrm{A}_{\mathrm{n}} \mathrm{Y}_{\mathrm{t}-\mathrm{n}}+\mathrm{HX}_{\mathrm{t}}+\mathrm{U}_{\mathrm{t}}
$$

where $Y_{t}$ refers to five endogenous variables (TCIu, TCIc, GDPu, GDPc and $\left.\mathrm{CO}_{2}\right)$ matrix $(5 \times 1)$, and subscript $t$ represents the most recent year or present time $(t) ; X_{t}$ is the exogenous variable (OPRICE) for the present time $(\mathrm{t})$; $\mathrm{H}$ is the coefficient matrix $(5 \times 1)$ for the exogenous variable; $U_{t}$ is the white noise matrix $(5 \times 1)$; $\mathrm{A}$ is the coefficient matrix $(5 \times 5)$, and $\mathrm{n}$ is the maximum number of lagging times; and $\mathrm{C}$ is the constant matrix $(5 \times 1)$.

\section{2 data}

In this paper, six clean energy were selected from the United States and China from 1992 to 2017,including solar energy, wind energy, biomass energy, hydro power, natural gas and nuclear power. The selected import and export data are all from UN comtrade Database. Other data involved in the research OPRICE and $\mathrm{CO}_{2}$ emission values values from the $\mathrm{BP}$ energy statistics Yearbook; $\mathrm{GDP}_{\mathrm{c}}$ and $\mathrm{GDP}_{\mathrm{u}}$ values from the World Bank Database; TRADE values from UN comtrade Database; the American energy consumption data originated from U.S. Energy Information Administration; Chinese energy consumption data originated from NBS.

\section{Results}

\subsection{International comparative analysis of clean energy between USA and China}

According to formula (2), calculate American and Chinese revealed competitiveness(RC) of solar energy, wind energy, biomass energy, hydropower, natural gas and nuclear power separately; the results are shown in table 1 and 2. According to table 1, the United States have competitive advantage in the aspects of biomass energy,hydropower and nuclear power. Numerical $\mathrm{RC}_{\mathrm{u}}$ all greater than 0 from 1992 to 2017, among it numerical $\mathrm{RC}_{\mathrm{u}}$ in biomass energy mostly between 1 and 2, always maintained the strong advantage of competitiveness; numerical $\mathrm{RC}_{\mathrm{u}}$ in hydropower mostly between 0 and 1 ; while numerical $\mathrm{RC}_{\mathrm{u}}$ in nuclear power show a trend of declining, the number had been greater than 1 from 1992 
to 2004 . However the number has maintained between 0 and 1 since 2007, it indicates the advantage of competitiveness is narrowing; numerical $\mathrm{RC}_{\mathrm{u}}$ in solar energy has been always less than 0 since 2011, it does not has the advantage of competitiveness; numerical $\mathrm{RC}_{\mathrm{u}}$ in wind energy mostly greater than 0 , while it had been less than 0 continuously in 2016 and 2017, it shows weak advantage of competitiveness; numerical $\mathrm{RC}_{\mathrm{u}}$ in natural gas less than 0 in most years, while it shows a trend of increasing on the whole, the number has been greater than 0 since 2016 and 2017 and has demonstrated a certain competitiveness.

On the basis of table 2, China has a certain competitiveness in the aspects of solar energy, wind energy and hydropower, numerical $\mathrm{RC}_{\mathrm{u}}$ has been greater than 0 since 2008; numerical $\mathrm{RC}_{\mathrm{u}}$ in biomass energy and natural gas, the positive and negative values are almost divided. Among it, numerical $\mathrm{RC}_{\mathrm{u}}$ in biomass energy had been less than 0 continuously from 2014 to 2017; numerical $\mathrm{RC}_{\mathrm{u}}$ in natural gas had been less than 0 since 2007 and had the trend of expanding; numerical $\mathrm{RC}_{\mathrm{u}}$ in nuclear energy had been always less than 0 except 2016 , while the value shows an upward trend from 1992-2017. It indicates that although China's nuclear energy lacks of international competitiveness, it is growing stronger.

Table1. The dominant advantage of clean energy in American $(\mathrm{RCu})$

\begin{tabular}{|c|c|c|c|c|c|c|}
\hline & $\begin{array}{l}\text { Solar } \\
\text { energy }\end{array}$ & $\begin{array}{l}\text { Wind } \\
\text { energy }\end{array}$ & $\begin{array}{l}\text { Biomass } \\
\text { energy }\end{array}$ & $\begin{array}{l}\text { hydropow } \\
\text { er }\end{array}$ & $\begin{array}{l}\text { Nutural } \\
\text { gas }\end{array}$ & $\begin{array}{l}\text { Nuclear } \\
\text { power }\end{array}$ \\
\hline 1992 & -0.25267 & 0.823327 & 1.46423 & 0.658144 & -1.43109 & 1.431507 \\
\hline 1993 & -0.10275 & 0.790399 & 1.695647 & 0.932849 & -1.90645 & 1.688314 \\
\hline 1994 & -0.02764 & 0.465383 & 1.808958 & 1.237579 & -1.74677 & 1.655328 \\
\hline 1995 & -0.10891 & 0.430097 & 2.102543 & 0.900233 & -1.29537 & 1.6128 \\
\hline 1996 & 0.056255 & 0.198845 & 1.466794 & 0.341088 & -1.7552 & 1.263414 \\
\hline 1997 & 0.219995 & 0.549698 & 1.934143 & 0.28415 & -1.95445 & 1.331856 \\
\hline 1998 & 0.393675 & 0.228953 & 1.381831 & 1.26562 & -2.15625 & 1.520544 \\
\hline 1999 & 0.270151 & 0.460855 & 1.484365 & 1.14141 & -2.40604 & 1.561062 \\
\hline 2000 & 0.299306 & 0.484995 & 0.690177 & 1.064019 & -2.7522 & 1.571996 \\
\hline 2001 & 0.425381 & 0.224239 & 0.42418 & 0.62366 & -2.66334 & 1.580919 \\
\hline 2002 & 0.626312 & 0.311258 & 1.005945 & 0.160002 & -1.67967 & 1.394087 \\
\hline 2003 & 0.703929 & 0.115663 & 1.495604 & 0.237094 & -1.80334 & 1.180116 \\
\hline 2004 & 0.933652 & 0.647919 & 1.314585 & 0.335975 & -1.6219 & 1.182141 \\
\hline 2005 & 1.123239 & 0.184722 & 1.724873 & 0.420621 & -1.65827 & 0.808448 \\
\hline 2006 & 0.945101 & 0.118499 & 0.730978 & 0.550143 & -1.80657 & 1.020763 \\
\hline 2007 & 0.97211 & -0.39749 & 1.485844 & 0.295254 & -1.5688 & 0.643411 \\
\hline 2008 & 0.947227 & -0.47359 & 1.16675 & 0.568509 & -1.33634 & 0.714883 \\
\hline 2009 & 0.874692 & -0.38541 & 1.676552 & 0.665509 & -0.89511 & 0.285195 \\
\hline 2010 & 0.641761 & -0.00691 & 2.047874 & 0.354663 & -0.72119 & 0.731136 \\
\hline 2011 & 0.108079 & -0.00689 & 1.853542 & 0.335729 & -0.27227 & 0.793544 \\
\hline 2012 & -0.14724 & 0.047101 & 1.279202 & 0.627213 & 0.164595 & 0.802602 \\
\hline 2013 & -0.09137 & 0.524291 & 1.362764 & 0.307718 & -0.23301 & 0.892871 \\
\hline 2014 & -0.12219 & 0.341215 & 1.981662 & 0.726588 & -0.27709 & 0.650702 \\
\hline 2015 & -0.43828 & 0.018924 & 2.046689 & 0.472854 & -0.07635 & 0.551733 \\
\hline 2016 & -0.555 & -0.26098 & 2.266701 & 0.597585 & 0.25407 & 0.647084 \\
\hline 2017 & -0.10702 & -0.32382 & 1.784331 & 0.589235 & 0.57288 & 0.371447 \\
\hline
\end{tabular}

Table2. The dominant advantage of clean energy inChina $\left(\mathrm{RC}_{\mathrm{c}}\right)$

\begin{tabular}{|c|c|c|c|c|c|c|}
\hline & $\begin{array}{c}\text { Solar } \\
\text { energy }\end{array}$ & $\begin{array}{c}\text { Wind } \\
\text { energy }\end{array}$ & $\begin{array}{c}\text { Biomass } \\
\text { energy }\end{array}$ & hydropower & Nutural gas & $\begin{array}{c}\text { Nuclear } \\
\text { power }\end{array}$ \\
\hline 1992 & 0.749491 & -1.15507 & 2.149695 & -1.21417 & 0.470358 & -2.48853 \\
\hline 1993 & 0.596237 & -1.09572 & 3.369925 & -0.07914 & -0.06829 & -3.58755 \\
\hline 1994 & 0.716468 & -1.86498 & 3.911891 & -1.20263 & -0.16888 & -4.37435 \\
\hline 1995 & 0.357729 & -1.11443 & 1.569672 & -1.34169 & 0.586284 & -3.66115 \\
\hline 1996 & -0.09371 & -0.99959 & -1.72361 & -0.81719 & -0.46833 & -2.09496 \\
\hline 1997 & -0.668 & -1.27662 & -0.83755 & -1.12303 & 1.459167 & -2.28752 \\
\hline 1998 & -0.94505 & -1.39702 & -1.14081 & -1.90222 & 1.615955 & -2.63794 \\
\hline 1999 & -0.89681 & -1.45332 & 0.170342 & -1.34213 & 2.094545 & -3.65176 \\
\hline 2000 & -1.0234 & -1.09809 & -1.22546 & -0.81844 & 2.660969 & -3.27184 \\
\hline
\end{tabular}




\begin{tabular}{|l|l|l|l|l|l|c|}
\hline 2001 & -1.14013 & -0.97568 & -0.34264 & -0.23619 & 2.773108 & -2.44777 \\
\hline 2002 & -1.43499 & -0.88763 & -0.83868 & -1.36133 & 2.857843 & -2.97851 \\
\hline 2003 & -1.49046 & -0.67647 & -0.42128 & -1.61749 & 2.351963 & -3.5479 \\
\hline 2004 & -1.17916 & -0.85792 & -1.35931 & -1.35831 & 1.907615 & -3.18091 \\
\hline 2005 & -0.839 & -0.79522 & -1.23434 & -1.1729 & 2.16633 & -2.27592 \\
\hline 2006 & -0.55086 & -0.48043 & 0.764036 & -1.03899 & 0.983452 & -1.7675 \\
\hline 2007 & -0.2047 & -0.30847 & 0.219804 & -0.58753 & -0.08451 & -1.57208 \\
\hline 2008 & 0.137091 & 0.184931 & 0.904455 & 0.458652 & -0.25289 & -1.36953 \\
\hline 2009 & 0.381732 & 0.483213 & 0.51162 & 1.651417 & -0.33256 & -1.40069 \\
\hline 2010 & 0.772489 & 0.615924 & 0.697698 & 1.804509 & -1.16112 & -1.06014 \\
\hline 2011 & 0.758041 & 1.019464 & 0.373536 & 2.243867 & -2.12069 & -1.5848 \\
\hline 2012 & 0.447676 & 1.181314 & -0.48682 & 2.966245 & -2.26888 & -1.22611 \\
\hline 2013 & 0.306225 & 1.337201 & 0.050388 & 2.844173 & -2.61919 & -0.87331 \\
\hline 2014 & 0.267983 & 1.196968 & -0.45612 & 3.435555 & -2.69627 & -0.45299 \\
\hline 2015 & 0.203402 & 1.346131 & -1.06965 & 3.729066 & -2.2413 & -0.08727 \\
\hline 2016 & 0.14577 & 1.670409 & -1.58717 & 3.329642 & -2.13836 & 0.173865 \\
\hline 2017 & 0.250388 & 1.509605 & -1.39292 & 2.727687 & -2.46869 & -0.27797 \\
\hline
\end{tabular}

\subsection{The trade complementary relationship in clean energy}

Based on Equation (3), the Trade Complementary index $\left(\mathrm{RC}_{\mathrm{u}}\right)$ are calculated for solar energy, wind energy, biomass energy, water energy, natural gas and nuclear power of the US and China, and the results are shown in Table (3) and Table (4).From the angle of the United States, its exports of solar energy, biomass energy and nuclear energy are highly complementary to China, while those of wind energy, hydroenergy and natural gas are less complementary. In terms of solar energy, $\mathrm{RC}_{\mathrm{u}}$ values has been greater than 1 continuously since 1996; In terms of biomass energy, $\mathrm{RC}_{\mathrm{u}}$ values fluctuates a lot. However, it has been on an upward trend since 2008, and the value has been greater than 1 since 2015 . In terms of nuclear power, in recent years, except for 2014 and 2015, the $\mathrm{RC}_{\mathrm{u}}$ value is greater than 1 most years. In terms of wind energy and hydroenergy energy, the $\mathrm{RC}_{\mathrm{u}}$ values of wind energy and water energy are in a downward trendbasically, respectively dropping from $7.17,2.45$ in 1992 to $0.230,0.090$ in 2017, thus indicating that complementarity is weakening. Although the $\mathrm{RC}_{\mathrm{u}}$ value of natural gas has always been less than 1 , it is in an upward trend totally, rising from 0.003 in 1992 to 0.448 in 2017, which indicates that although the complementarity is still weak, this relationship is enhancing.

From the perspective of China, the export of solar and wind energy with the United States have a strong trade complementarity. The $\mathrm{RC}_{\mathrm{u}}$ value of solar energy is rising as a whole, from 0.66 in 1992 to 2.16 in 2017. The $\mathrm{RC}_{\mathrm{u}}$ value of wind energy fluctuates around 1 , and has been continuously greater than 1 since 2016 and 2017. In terms of biomass energy, complementarity is weak and is still in a trend of declining. $\mathrm{RC}_{\mathrm{u}}$ value dropped from 0.538 in 1992 to 0.040 in 2017; In terms of natural gas and hydroenergy, $\mathrm{RC}_{\mathrm{u}}$ value changes littler relatively, and the complementarity has been weak. In terms of nuclear power, although $\mathrm{RC}_{\mathrm{u}}$ value is small, it ison the rise as a whole, from 0.041 in 1992 to 0.443 in 2017.

Combined with table 1 and table 2, it can be found that in terms of solar energy, China has the advantage of export competitiveness internationally, while the United States lacks of competitive advantages. However, bilateral trade between China and the United States is mutually complementary.Obviously, the United States has the technology and advantages in high-end solar products, while China has the competitive advantages in low-end products. The two countries have the advantages in different areas, so their import and export are complementary. In wind energy, China has a competitive export advantage and a complementary relationship with the United States.In biomass energy and nuclear energy, the United States has export competitiveness and also have complementary to China. In the aspect of hydroenergy, China and the United States both have competitive advantages in the international market, but they are not complementary to each other. This shows that the export homogeneity of hydroenergy products of the two countries is obvious, which is mainly reflected in the competitive relationship. In terms of natural gas, the United States has began to have a certain competitive advantage in recent years, China does not have a competitive edge, has yet to form a complementary relationship between the two countries, but the relationship is enhancing, although the United States is increasing the production and exportation of natural gas, China is increasing imports, the trade of natural gas volume between China and the United States is still small, trade increment is not enough to reflect the international relations of the import and export in both countries.

Table 3. US-China Clean Energy Trade Complementary Index ( $\left.\mathrm{TCI}_{\mathrm{u}}\right)$ 


\begin{tabular}{|c|c|c|c|c|c|c|}
\hline & $\begin{array}{l}\text { Solar } \\
\text { energy }\end{array}$ & $\begin{array}{l}\text { Wind } \\
\text { energy }\end{array}$ & $\begin{array}{l}\text { Biomass } \\
\text { energy }\end{array}$ & $\begin{array}{l}\text { hydropow } \\
\text { er }\end{array}$ & $\begin{array}{l}\text { Nutural } \\
\text { gas }\end{array}$ & $\begin{array}{l}\text { Nuclear } \\
\text { power }\end{array}$ \\
\hline 1992 & $2.33 \mathrm{E}-01$ & $7.17 \mathrm{E}+00$ & $2.86 \mathrm{E}-01$ & $2.45 \mathrm{E}+00$ & $2.53 \mathrm{E}-03$ & $2.15 \mathrm{E}+00$ \\
\hline 1993 & $2.67 \mathrm{E}-01$ & $4.48 \mathrm{E}+00$ & $3.67 \mathrm{E}-02$ & $4.84 \mathrm{E}-01$ & $2.27 \mathrm{E}-03$ & 8.19E-01 \\
\hline 1994 & $3.65 \mathrm{E}-01$ & $5.03 \mathrm{E}+00$ & $2.74 \mathrm{E}-02$ & $1.56 \mathrm{E}+00$ & $5.55 \mathrm{E}-03$ & $3.45 \mathrm{E}+00$ \\
\hline 1995 & $6.14 \mathrm{E}-01$ & $4.10 \mathrm{E}+00$ & $1.12 \mathrm{E}-01$ & $4.46 \mathrm{E}+00$ & $4.70 \mathrm{E}-03$ & $3.54 \mathrm{E}+00$ \\
\hline 1996 & $1.10 \mathrm{E}+00$ & $4.12 \mathrm{E}+00$ & $3.77 \mathrm{E}+00$ & $1.96 \mathrm{E}+00$ & 4.90E-03 & $1.29 \mathrm{E}+00$ \\
\hline 1997 & $2.25 \mathrm{E}+00$ & $7.58 \mathrm{E}+00$ & $4.60 \mathrm{E}+00$ & $3.31 \mathrm{E}+00$ & $6.01 \mathrm{E}-03$ & $1.13 \mathrm{E}+00$ \\
\hline 1998 & $3.21 \mathrm{E}+00$ & $6.36 \mathrm{E}+00$ & $3.14 \mathrm{E}+00$ & $2.53 \mathrm{E}+00$ & $2.47 \mathrm{E}-03$ & $1.79 \mathrm{E}+00$ \\
\hline 1999 & $3.11 \mathrm{E}+00$ & $4.58 \mathrm{E}+00$ & $6.75 \mathrm{E}-01$ & $2.60 \mathrm{E}+00$ & $1.99 \mathrm{E}-03$ & $3.89 \mathrm{E}+00$ \\
\hline 2000 & $2.86 \mathrm{E}+00$ & $3.42 \mathrm{E}+00$ & $2.33 \mathrm{E}+00$ & $1.63 \mathrm{E}+00$ & $5.07 \mathrm{E}-04$ & $6.50 \mathrm{E}+00$ \\
\hline 2001 & $3.13 \mathrm{E}+00$ & $2.59 \mathrm{E}+00$ & $1.04 \mathrm{E}+00$ & $1.09 \mathrm{E}+00$ & 4.74E-04 & $3.90 \mathrm{E}+00$ \\
\hline 2002 & $3.75 \mathrm{E}+00$ & $2.24 \mathrm{E}+00$ & $1.69 \mathrm{E}+00$ & $1.44 \mathrm{E}+00$ & 9.84E-04 & $2.90 \mathrm{E}+00$ \\
\hline 2003 & $3.60 \mathrm{E}+00$ & $1.69 \mathrm{E}+00$ & $1.59 \mathrm{E}+00$ & 7.34E-01 & $8.21 \mathrm{E}-04$ & $2.83 \mathrm{E}+00$ \\
\hline 2004 & $3.86 \mathrm{E}+00$ & $2.24 \mathrm{E}+00$ & $1.16 \mathrm{E}+00$ & $7.06 \mathrm{E}-01$ & $1.64 \mathrm{E}-03$ & $1.78 \mathrm{E}+00$ \\
\hline 2005 & $4.05 \mathrm{E}+00$ & $1.77 \mathrm{E}+00$ & $2.07 \mathrm{E}+00$ & $1.21 \mathrm{E}+00$ & $1.03 \mathrm{E}-03$ & $1.12 \mathrm{E}+00$ \\
\hline 2006 & $3.57 \mathrm{E}+00$ & $1.60 \mathrm{E}+00$ & $1.14 \mathrm{E}+00$ & $1.43 \mathrm{E}+00$ & $2.06 \mathrm{E}-03$ & $1.36 \mathrm{E}+00$ \\
\hline 2007 & $3.50 \mathrm{E}+00$ & $1.15 \mathrm{E}+00$ & $8.36 \mathrm{E}-01$ & $1.03 \mathrm{E}+00$ & $1.10 \mathrm{E}-02$ & $1.02 \mathrm{E}+00$ \\
\hline 2008 & $2.67 \mathrm{E}+00$ & $7.66 \mathrm{E}-01$ & $3.47 \mathrm{E}-01$ & $5.72 \mathrm{E}-01$ & $1.08 \mathrm{E}-02$ & $1.23 \mathrm{E}+00$ \\
\hline 2009 & $1.97 \mathrm{E}+00$ & $5.64 \mathrm{E}-01$ & $4.51 \mathrm{E}-01$ & $1.93 \mathrm{E}-01$ & $1.67 \mathrm{E}-02$ & $1.19 \mathrm{E}+00$ \\
\hline 2010 & $1.22 \mathrm{E}+00$ & $5.52 \mathrm{E}-01$ & $5.87 \mathrm{E}-01$ & $1.70 \mathrm{E}-01$ & $4.60 \mathrm{E}-02$ & $1.06 \mathrm{E}+00$ \\
\hline 2011 & $1.19 \mathrm{E}+00$ & $4.48 \mathrm{E}-01$ & $5.03 \mathrm{E}-01$ & $8.36 \mathrm{E}-02$ & 7.84E-02 & $1.40 \mathrm{E}+00$ \\
\hline 2012 & $1.34 \mathrm{E}+00$ & $3.90 \mathrm{E}-01$ & $9.54 \mathrm{E}-01$ & $7.04 \mathrm{E}-02$ & $1.04 \mathrm{E}-01$ & $1.62 \mathrm{E}+00$ \\
\hline 2013 & $1.35 \mathrm{E}+00$ & $3.52 \mathrm{E}-01$ & $6.36 \mathrm{E}-01$ & $5.81 \mathrm{E}-02$ & $9.78 \mathrm{E}-02$ & $1.12 \mathrm{E}+00$ \\
\hline 2014 & $1.43 \mathrm{E}+00$ & 4.32E-01 & $6.58 \mathrm{E}-01$ & $1.88 \mathrm{E}-02$ & $1.53 \mathrm{E}-01$ & $9.55 \mathrm{E}-01$ \\
\hline 2015 & $1.28 \mathrm{E}+00$ & $3.26 \mathrm{E}-01$ & $1.34 \mathrm{E}+00$ & $1.66 \mathrm{E}-02$ & $1.66 \mathrm{E}-01$ & $9.24 \mathrm{E}-01$ \\
\hline 2016 & $1.33 \mathrm{E}+00$ & $1.96 \mathrm{E}-01$ & $1.89 \mathrm{E}+00$ & $3.26 \mathrm{E}-02$ & $3.17 \mathrm{E}-01$ & $1.09 \mathrm{E}+00$ \\
\hline 2017 & $1.51 \mathrm{E}+00$ & $2.30 \mathrm{E}-01$ & $1.18 \mathrm{E}+00$ & 8.98E-02 & $4.48 \mathrm{E}-01$ & $1.04 \mathrm{E}+00$ \\
\hline
\end{tabular}

Table 4. China-US Clean Energy Trade Complementary Index $\left(\mathrm{TCI}_{\mathrm{c}}\right)$

\begin{tabular}{|c|c|c|c|c|c|c|}
\hline & $\begin{array}{c}\text { Solar } \\
\text { energy }\end{array}$ & $\begin{array}{c}\text { Wind } \\
\text { energy }\end{array}$ & $\begin{array}{c}\text { Biomass } \\
\text { energy }\end{array}$ & $\begin{array}{c}\text { hydropow } \\
\text { er }\end{array}$ & $\begin{array}{c}\text { Nutural } \\
\text { gas }\end{array}$ & $\begin{array}{c}\text { Nuclear } \\
\text { power }\end{array}$ \\
\hline 1992 & $6.36 \mathrm{E}-01$ & $9.40 \mathrm{E}-01$ & $5.38 \mathrm{E}-01$ & $3.77 \mathrm{E}-01$ & $1.61 \mathrm{E}-02$ & $4.05 \mathrm{E}-02$ \\
\hline 1993 & $5.37 \mathrm{E}-01$ & $7.70 \mathrm{E}-01$ & $2.22 \mathrm{E}-01$ & $1.76 \mathrm{E}-01$ & $1.62 \mathrm{E}-02$ & $4.75 \mathrm{E}-03$ \\
\hline 1994 & $7.69 \mathrm{E}-01$ & $4.69 \mathrm{E}-01$ & $2.15 \mathrm{E}-01$ & $1.36 \mathrm{E}-01$ & $2.58 \mathrm{E}-02$ & $7.95 \mathrm{E}-03$ \\
\hline 1995 & $9.79 \mathrm{E}-01$ & $7.75 \mathrm{E}-01$ & $5.84 \mathrm{E}-02$ & $4.73 \mathrm{E}-01$ & $2.73 \mathrm{E}-02$ & $1.61 \mathrm{E}-02$ \\
\hline 1996 & $9.48 \mathrm{E}-01$ & $1.14 \mathrm{E}+00$ & $1.43 \mathrm{E}-01$ & $6.14 \mathrm{E}-01$ & $1.63 \mathrm{E}-02$ & $4.13 \mathrm{E}-02$ \\
\hline 1997 & $9.26 \mathrm{E}-01$ & $9.47 \mathrm{E}-01$ & $2.23 \mathrm{E}-01$ & $8.10 \mathrm{E}-01$ & $1.42 \mathrm{E}-01$ & $2.36 \mathrm{E}-02$ \\
\hline 1998 & $8.40 \mathrm{E}-01$ & $9.52 \mathrm{E}-01$ & $1.92 \mathrm{E}-01$ & $1.07 \mathrm{E}-01$ & $8.16 \mathrm{E}-02$ & $2.13 \mathrm{E}-02$ \\
\hline 1999 & $9.69 \mathrm{E}-01$ & $5.75 \mathrm{E}-01$ & $1.54 \mathrm{E}-01$ & $2.17 \mathrm{E}-01$ & $1.52 \mathrm{E}-01$ & $1.80 \mathrm{E}-02$ \\
\hline 2000 & $7.61 \mathrm{E}-01$ & $6.35 \mathrm{E}-01$ & $3.10 \mathrm{E}-01$ & $2.48 \mathrm{E}-01$ & $1.03 \mathrm{E}-01$ & $4.63 \mathrm{E}-02$ \\
\hline 2001 & $6.53 \mathrm{E}-01$ & $7.16 \mathrm{E}-01$ & $4.45 \mathrm{E}-01$ & $4.61 \mathrm{E}-01$ & $9.99 \mathrm{E}-02$ & $6.37 \mathrm{E}-02$ \\
\hline 2002 & $4.78 \mathrm{E}-01$ & $6.12 \mathrm{E}-01$ & $2.42 \mathrm{E}-01$ & $3.14 \mathrm{E}-01$ & $8.32 \mathrm{E}-02$ & $3.31 \mathrm{E}-02$ \\
\hline 2003 & $4.01 \mathrm{E}-01$ & $7.20 \mathrm{E}-01$ & $2.20 \mathrm{E}-01$ & $1.15 \mathrm{E}-01$ & $4.94 \mathrm{E}-02$ & $2.36 \mathrm{E}-02$ \\
\hline 2004 & $4.66 \mathrm{E}-01$ & $4.69 \mathrm{E}-01$ & $7.56 \mathrm{E}-02$ & $1.30 \mathrm{E}-01$ & $5.29 \mathrm{E}-02$ & $2.14 \mathrm{E}-02$ \\
\hline 2005 & $5.70 \mathrm{E}-01$ & $5.74 \mathrm{E}-01$ & $9.29 \mathrm{E}-02$ & $2.46 \mathrm{E}-01$ & $4.09 \mathrm{E}-02$ & $4.46 \mathrm{E}-02$ \\
\hline 2006 & $8.00 \mathrm{E}-01$ & $7.20 \mathrm{E}-01$ & $9.59 \mathrm{E}-01$ & $2.91 \mathrm{E}-01$ & $2.74 \mathrm{E}-02$ & $6.84 \mathrm{E}-02$ \\
\hline 2007 & $1.08 \mathrm{E}+00$ & $9.89 \mathrm{E}-01$ & $1.85 \mathrm{E}-01$ & $4.25 \mathrm{E}-01$ & $3.81 \mathrm{E}-02$ & $8.72 \mathrm{E}-02$ \\
\hline 2008 & $1.19 \mathrm{E}+00$ & $1.17 \mathrm{E}+00$ & $2.11 \mathrm{E}-01$ & $5.13 \mathrm{E}-01$ & $2.53 \mathrm{E}-02$ & $1.20 \mathrm{E}-01$ \\
\hline
\end{tabular}




\begin{tabular}{|l|l|l|l|l|l|l|}
\hline 2009 & $1.21 \mathrm{E}+00$ & $1.13 \mathrm{E}+00$ & $1.18 \mathrm{E}-01$ & $5.16 \mathrm{E}-01$ & $2.47 \mathrm{E}-02$ & $1.86 \mathrm{E}-01$ \\
\hline 2010 & $1.39 \mathrm{E}+00$ & $9.11 \mathrm{E}-01$ & $1.35 \mathrm{E}-01$ & $7.24 \mathrm{E}-01$ & $2.63 \mathrm{E}-02$ & $1.57 \mathrm{E}-01$ \\
\hline 2011 & $2.29 \mathrm{E}+00$ & $1.14 \mathrm{E}+00$ & $1.05 \mathrm{E}-01$ & $5.64 \mathrm{E}-01$ & $1.13 \mathrm{E}-02$ & $1.19 \mathrm{E}-01$ \\
\hline 2012 & $2.42 \mathrm{E}+00$ & $1.08 \mathrm{E}+00$ & $1.45 \mathrm{E}-01$ & $7.30 \mathrm{E}-01$ & $8.09 \mathrm{E}-03$ & $1.90 \mathrm{E}-01$ \\
\hline 2013 & $2.00 \mathrm{E}+00$ & $7.00 \mathrm{E}-01$ & $1.51 \mathrm{E}-01$ & $7.35 \mathrm{E}-01$ & $7.94 \mathrm{E}-03$ & $1.70 \mathrm{E}-01$ \\
\hline 2014 & $2.11 \mathrm{E}+00$ & $8.51 \mathrm{E}-01$ & $4.81 \mathrm{E}-02$ & $2.83 \mathrm{E}-01$ & $1.14 \mathrm{E}-02$ & $2.65 \mathrm{E}-01$ \\
\hline 2015 & $2.44 \mathrm{E}+00$ & $9.09 \mathrm{E}-01$ & $4.39 \mathrm{E}-02$ & $4.30 \mathrm{E}-01$ & $1.41 \mathrm{E}-02$ & $3.61 \mathrm{E}-01$ \\
\hline 2016 & $2.67 \mathrm{E}+00$ & $1.02 \mathrm{E}+00$ & $3.03 \mathrm{E}-02$ & $5.01 \mathrm{E}-01$ & $2.19 \mathrm{E}-02$ & $5.13 \mathrm{E}-01$ \\
\hline 2017 & $2.16 \mathrm{E}+00$ & $1.17 \mathrm{E}+00$ & $4.02 \mathrm{E}-02$ & $7.62 \mathrm{E}-01$ & $1.74 \mathrm{E}-02$ & $4.43 \mathrm{E}-01$ \\
\hline
\end{tabular}

\subsection{Analysis based on VAR model}

The annual $\mathrm{RC}_{\mathrm{u}}$ and $\mathrm{RC}_{\mathrm{c}}$ values of each clean energy product are obtained through previous calculation. In order to build the VAR model, the values of Table 3 and Table 4 are weighted and summed according to the proportion of the export quantity of each product in the total export quantity, and then the $\mathrm{RC}_{\mathrm{u}}$ and $\mathrm{RCc}$ values of the total clean energy are obtained. At the same time, in order to eliminate the possible heteroscedasticity, logarithm values of $\mathrm{RC}_{\mathrm{u}}, \mathrm{RC}_{\mathrm{c}}, \mathrm{GDP}_{\mathrm{u}}, \mathrm{GDP}_{\mathrm{c}}$ and OPRICE are utilized, and the corresponding variables will be $\mathrm{LRC}_{\mathrm{u}}, \mathrm{LRC}_{\mathrm{c}}, \mathrm{LGDP}_{\mathrm{u}}$,
LGDP. $_{\mathrm{c}}$. Before building the VAR model, it is necessary to examine the stationarity of time series data. The unit root test is conducted by using the $\mathrm{ADF}$ (Augmented Dickey Fuller) through Eviews 10. It is found that all sequences have first-order single integration, that is, after the first difference operations, each new time series (DLTIIu, DLRC $u$, DLRC $_{c}$, DLGDPc or DLOPRICE) displays the stationarity,and the results are shown in Table 5. It is found that the sequences DLRCc, DLRCu and DLOPRICE are stable at $1 \%$ significant level, while DLGDPc, DLGDPu and $\mathrm{DLCO}_{2}$ are stable at $10 \%$ significant level. Therefore, the VAR model can be constructed under this condition.

Table 5. ADF Unit Root Test

\begin{tabular}{|l|l|l|l|l|l|l|}
\hline & DLRCc & DLRCu & DLGDPc & DLGDPu & DLCO $_{2}$ & DLOPRICE \\
\hline ADF-value & -3.994 & -5.708 & -2.835 & -2.689 & -2.658 & -4.593 \\
\hline P-value & 0.006 & 0.000 & 0.068 & 0.091 & 0.096 & 0.001 \\
\hline
\end{tabular}

According to table 6, it can be found that LR, FPE, HQ and SC methods judge the optimal lag period of VAR model to be 1, while AIC method determines the optimal lag base to be 2 . Therefore, we take the lag base to be 1 , namely VARTCI(1). $\operatorname{VAR}_{\text {TII }}$ (1) model is subjected to stability test via AR root graphical method. If the reciprocal values of the characteristic roots are all within the unit circle, that is, the reciprocal values are all less than 1, it indicates that VAR(1) is stable. Otherwise, it indicates that the model is unstable, and we need to reset and test the lag period of the model. As is illustrated in Figure 1, reciprocal values of the characteristic roots are all within the unit circle, indicating that VARTII(1) is stable and lag time is selected properly. Thus, we can analyze impulse response.

Table 6. Lag orders of the VARTCI(1) model

\begin{tabular}{|c|c|c|c|c|c|c|}
\hline Lag & $\log L$ & LR & FPE & AIC & $\mathrm{SC}$ & HQ \\
\hline 0 & 264.2518 & NA & $1.73 \mathrm{e}-16$ & -22.10885 & -21.61516 & -21.98469 \\
\hline 1 & 304.1786 & $\begin{array}{l}55.55044 \\
*\end{array}$ & $5.19 \mathrm{e}-17 *$ & -23.40684 & $-21.6789 *$ & $-22.9722 *$ \\
\hline 2 & 332.2053 & 26.80807 & $6.39 \mathrm{e}-17$ & $-23.6700^{*}$ & -20.70786 & -22.92505 \\
\hline
\end{tabular}

* indicates lag order selected by the criterion;

LR:sequential modified LR test statistic (each test at 5\% level); FPE: Final prediction error; AIC: Akaike

information criterion ; SC: Schwarz information criterion; HQ: Hannan-Quinn information criterion 


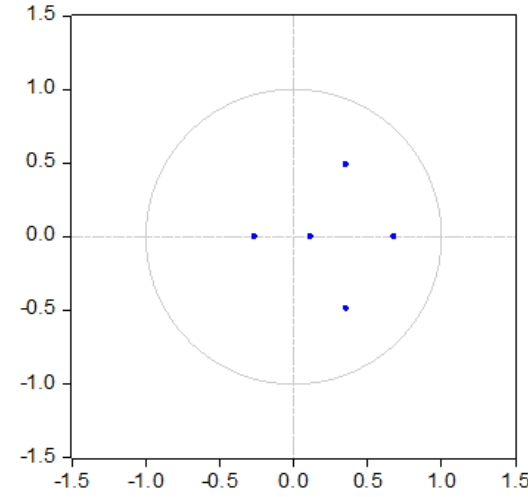

Fig.1. Inverse roots of AR characteristic polynomial

The Gross Domestic Product (GDPc and GDPu) and total carbon dioxide $\left(\mathrm{CO}_{2}\right)$ emissions may be affected by the clean energy trade cooperation. Therefore, next we analyze the pulse response of VARTII (1) model. The pulse response functions are shown in Figure 2 to 4 . In the Figures, the vertical axis is the impulse responses, and the horizontal axis is the lag time (year) after the initial positive impacts are applied to $\mathrm{DLTII}_{\mathrm{u}}$ or $\mathrm{DLTII}_{\mathrm{C}}$. The impact value is the respective standard deviation value in the data.

According to figure 2, $\mathrm{TCI}_{\mathrm{c}}$ will cause negative response for $\mathrm{DLCO}_{2}$.Comparatively speaking,DLTIc has a more significant effect on carbon emissions. The reason is that clean energy accounts for a relatively small proportion of total energy consumption in China, and the improvement of energy efficiency brought by the development of clean energy industry in the early stage will be more obvious.Cumulatively, the negative $\mathrm{DLCO}_{2}$ response due to DLTCI ${ }_{u}$ and DLTCI ${ }_{C}$ are -0.001428 and -0.002828 respectively,as tabulated in Table 7. Figure 3 illustrates the impulse responses of $\operatorname{DLGDP}_{u}$ due to $\mathrm{DLTCI}_{\mathrm{u}}$ and DLTCI$C$. For the impact of DLTCIC, the initial response of DLGDPu is negative, positive from the end of the second term, and the cumulative response is 0.000160 (table 7).This may be due to the initial negative impact of Chinese exports to the United States on U.S. GDP, but in the end, the cooperation between the two countries contributed to the growth of U.S. GDP.

Referring to Figure 4 and Table 7, $\mathrm{DLTCI}_{\mathrm{u}}$ or DLTCI $_{C}$ may cause a negative impact on DLGDP $_{C}$ and the cumulative responses due to $\mathrm{DLTII}_{u}$ and $\mathrm{DLTII}_{\mathrm{C}}$ are -0.005593 and -0.008079 , respectively. This shows that the cooperation of clean energy between China and the United States can not promote the growth of China's GDP. The reason is that China's clean energy is still in its early stage of development. The development of clean energy industry and the increase of investment in clean energy have crowded out investment in other industries, thus slowing down the growth of GDP.

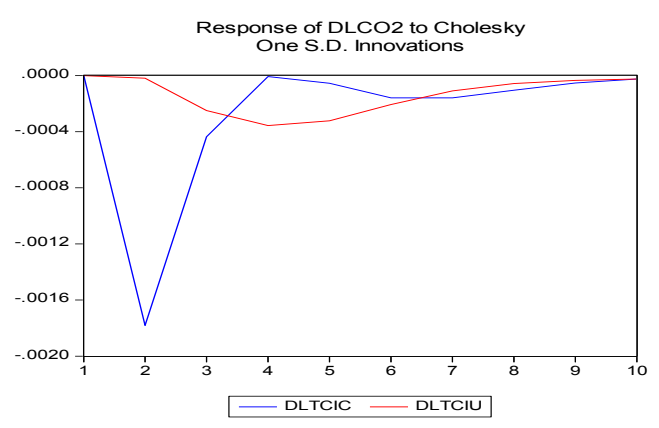

Fig.2. Response of $\mathrm{DLCO}_{2}$ in $\mathrm{VAR}_{\mathrm{TCI}}(1)$

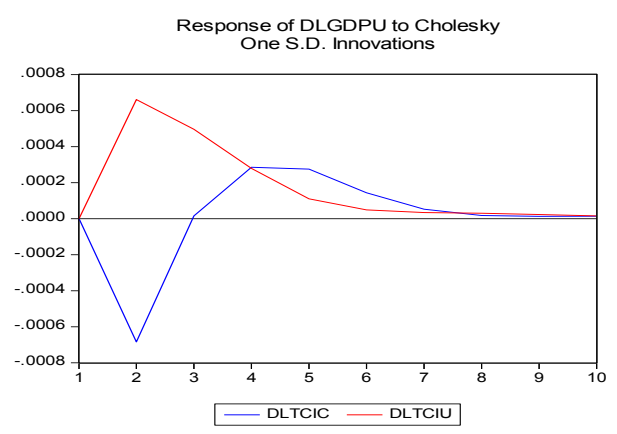

Fig.3. Response of DLGDPu in $\operatorname{VAR}_{\mathrm{TCI}}(1)$

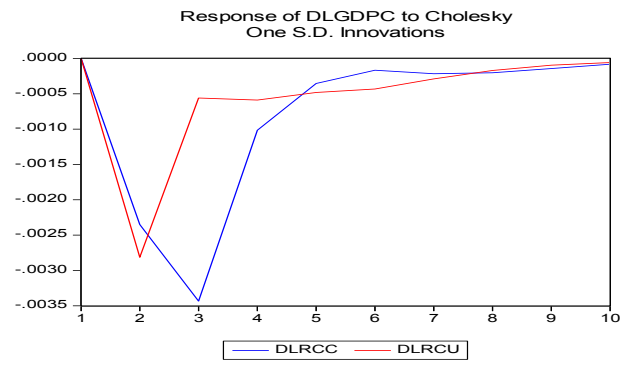

Fig. 4. Response of DLGDPc in VARTCI(1)

Table 7. Total impulse response.

\begin{tabular}{|l|l|l|l|}
\hline $\begin{array}{l}\text { Response } \\
\text { Impulse }\end{array}$ & $\mathrm{DLCO}_{2}$ & DLGDP $_{\mathrm{u}}$ & DLGDP $_{\mathrm{c}}$ \\
\hline DLTCI $_{\mathrm{u}}$ & -0.005293 & 0.001721 & -0.005593 \\
\hline DLTCI $_{\mathrm{C}}$ & -0.004255 & 0.000160 & -0.008079 \\
\hline
\end{tabular}

\section{Conclusions and policy implications}

This paper uses the revealed competitiveness index $(\mathrm{RC})$ to measure the export advantages of China and the United States in the international market, that is, the international competitiveness.The United States has certain competitive advantages in biomass energy and nuclear energy, while China has certain competitive advantages in solar energy and wind energy. At the same time, the calculation between the two countries Trade Complementarity Index (TCI), U.S. exports in terms of solar energy, biomass energy and nuclear energy has strong complementarity with China's imports in terms of solar energy, wind energy, China's exports to the United 
States imports has strong complementarity, there is a strong potential for cooperation.In the aspect of water energy, China and the United States are not complementary to each other, mainly in the form of competition.In terms of natural gas, the complementarity between the two countries is weak, but it is likely to increase.Therefore, on the whole, the trade on clean energy is highly complementary and has great potential for cooperation between the two countries.Based on the VAR model built by $\mathrm{TCI}_{\mathrm{c}}$ and $\mathrm{TCI}_{\mathrm{u}}$, it can be found that clean energy trade cooperation can help curb $\mathrm{CO}_{2}$ emissions and promote the growth of GDP in the United States.But since China is in the early stages of developing clean energy, clean energy trade cooperation will cause a decline of China's GDP.

From the perspective of the development goals and policy orientation of clean energy in both countries, China and the United States attach great importance to the development of clean energy, and the United States has mature experience and technology and needs to explore new markets, while China is just in the early stage of development and has great market demand.Obviously, bilateral trade cooperation is beneficial to both countries. Theoretically, there is a strong complementarity, and practically, there is a large space for win-win cooperation.At present, it is necessary to improve the intellectual property system and relevant legal system jointly recognized by China and the United States as soon as possible.In terms of patent application and protection, it is necessary to jointly establish a transparent management method and an effective review system, ensure the standardization of application and review, strengthen cooperation and communication between China and the United States, crack down on cross-border ipr violations and crimes, and maintain the order of bilateral trade.In the process of implementation, the United States should gradually relax technical control, and China should speed up the opening of market access.Only in this way can clean energy trade cooperation come into being due to different division of labor in the industrial chain, that is, high-end products from the United States enter the Chinese market, while low-end products from China enter the American market.The capital access and exit mechanism should be improved to ensure the legalization and transparency of capital investment and protect the legitimate rights and interests of enterprises.

\section{Acknowledgements}

This research is partially funded by Guizhou Province Education Department (Grant No.2016087), and education research funding from Guizhou University of Commerce (Grant No. 2018YYLZY03).

\section{References}

1. Meng F Y, Zhou P. Ineffciency and Congestion Assessment of Mix Energy Consumption in 16 APEC Countries by Using DEA Window Analysis [J].Energy Procedia, 2014, 61(36) : 2518 2523.
2. Wu L Y, Zeng W H. R esearch on the Contribution of Structure Adjustment on $\mathrm{SO}^{2}$ Emissions $\mathrm{R}$ eduction - Case Study of Shijingshan District Beijing[J]. Procedia Environmental Sciences, 2013, 18( 114) : 849 855.

3. Stefan Bojnec a,and ImreFerto. Complementarities of trade advantage and trade competitiveness measures. Applied Economics, 2012, 44, 399-408.

4. Jing Shuai,et al.2018.Are China's solar PV products competitive in the context of the Belt and Road Initiative?Energy Policy, vol. ,pp. 559-568.

5. GholamrezaFathipour, Pratibha S. Gaikwad,2018. Comparative Advantage in Indian Economy: 1990-2014. Information Management and Business Review. Vol. 10, No. 1, pp. 23-30.

6. Balassa Bela. Trade liberalization and revealed comparative advantage[J].The Manchester School of Economics and Social Studies, 1965(2):99-123.

7. VeselinHadzhiev,2014. More on Measuring the Overall Revealed Comparative Advantage. TEM Journal, vol. 3, no.3, pp. 250-256, 2014.

8. Mayank Gupta, Harish Kumar, 2017. Revealed Comparative Advantage: An Analysis of Exports of Rwanda. Journal of Economics and Finance. Volume 8, Issue 3, PP 69-76.

9. Greenaway, D. \& Milner, C. (1993). Trade and Industrial Policy in Developing Countries: A Manual of Policy Analysis. Michigan Publishing, US: University of Michigan Press.

10. Vollrath, T. L. (1991). A theoretical evaluation of alternative trade intensity measures of revealed comparative advantage. Weltwirtschaftliches Archiv, 127(2), 265-280.

11. Drysdale, P., 1969. Japan, Australia and New Zealand: The Prospects for Western Pacific Economic Integration. Economic Record, 45(3), pp. 321-342.

12. Zheng, X., Jia, L., Bao, J. and Chen, J., 2018. A Study ofTrade Complementarity between China and the BalticStates and its Development Strategies. Amfiteatru Economic, 20(49), pp. 788-803.

13. Wei Zhang, Jun Yang, Pengfei Sheng, Xuesong Li, XingwuWang.Potential cooperation in renewable energy between Chinaand the United States of America.Energy Policy 75(2014) 403-409. 